\title{
STANDAR PERENCANAAN KEPERAWATAN DALAM ASUHAN KEPERAWATAN
}

\author{
Esty Purnama Sari
}

\section{Estypurnamasari97@gmail.com}

\section{Latar Belakang}

Perencanaan merupakan tahap selanjutnya setelah pengkajian dan penentuan diagnosa keperawatan. Perencanaan juga merupakan petunjuk tertulis yang menggambarkan secara tepat mengenai rencana tindakan yang dilakukan terhadap pasien sesuai dengan tingkat kebutuhan berdasarkan diagnosa keperawatan yang muncul. Untuk itu rencana tindakan yang baik tentunya harus berdasarkan pada diagnosa keperawatan yang telah dirumuskan (Hartati, Handoyo, Anis, 2010). Tahap perencanaan merupakan suatu proses penyusunan berbagai intervensi keperawatan yang dibutuhkan untuk mencegah, menurunkan atau mengurangi masalah-masalah klien. Dalam menentukan tahap perencanaan bagi perawat diperlukan berbagai pengetahuan dan keterampilan diantaranya pengetahuan tentang kekuatan dan kelemahan klien, nilai dan kepercayaan klien, batasan praktek keperawatan, peran dari tenaga kesehatan lainnya, kemampuan dalam memecahkan masalah, mengambil keputusan, menulis tujuan serta memilih dan membuat strategi keperawatan yang aman dalam memenuhi tujuan, menulis instruksi keperawatan serta. kemampuan dalam melaksanakan kerja sama dengan tingkat kesehatan lain. Rencana tindakan keperawatan dibuat berdasarkan kebutuhan klien. Pelaksanaan praktik keperawatan dilakukan sesuai dengan rencana yang telah disepakati bersama antara klien dan keluarganya. Pelaksanaan praktik keperawatan harus berpedoman pada standar profesi (Putra, A. 2010). Perencanaan asuhan keperawatan yang tidak saling berkesinambungan dalam rekam medis berdampak pada kualitas asuhan pasien. Tujuan studi ini adalah menganalisis standar asuhan keperawatan dalam asuhan keperawatan agar lebih optimal.

Kata kunci : Perencanaan Keperawatan, Proses Keperawatan, Standar Asuhan Keperawatan 


\section{Metode}

Metode penelitian yang digunakan yaitu bersumber dari beberapa literature jurnal, Jurnal ini dibatasi dengan tahun paling tua 2012. Jumlah referensi jurnal yang digunakan sebanyak 12 referensi jurnal. Metode menggunakan literatur jurnal ini memiliki kelebihan yaitu dari setiap literatur jurnal benar adanya. Dari hasil pencarian kemudian diolah dan dianalisis sehingga menghasilkan sebuah pembahasan dan kesimpulan dari topik yang ditetapkan, . Kemudian setelah data dari literatur jurnal terkumpul selanjutnya akan dilakukan pengolahan berupa mengobservasi dan mencermati setiap data dari literatur jurnal tersebut.

\section{Hasil}

Hasil analisis karateristik responden menurut usia adalah rentang usia 21-30 tahun adalah 14 perawat dengan persentase $35 \%$, usia 31-40 tahun adalah 20 perawatdengan persentase $50 \%$ serta usia lebih dari40 tahun 6 perawat dengan persentase 15\%.Pada tahapan dewasa muda individu telahmulai menata kehidupannya untukmencapai kestabilan. Hal senadadiungkapkan pula oleh Potter dan Perry (2005) bahwa seseorang yang telahmemasuki tahap dewasa muda diharuskan untuk menentukan tanggung jawab,mencapai kestabilan dalam hal pekerjaan,dan memiliki hubungan dalam tahap yang lebih intim. Oleh karena itu pada tahap usia dewasa muda seharusnya perawat memiliki perilaku yang stabil dan pencapaian perilaku baik. Hasil penelitian menunjukkan dengan jenis kelamin perempuan sama banyak dengan responden dengan jenis kelamin laki-laki. Dimana responden berjenis kelamin perempuan dan jenis kelamin laki-laki berjumlah 20 perawat dengan persentase masing-masing 50\%. Hasil penelitian menunjukkan responden dengan masa kerja kurang dari 3 tahun berjumlah 20 orang dan masa kerja lebih dari 3 tahun berjumlah 20 orang dengan persentase masing-masing 50\%. Hasil penelitian menunjukkan responden dengan tingkat pendidikan DIII keperawatan berjumlah 18 orang dengan persentase $45 \%$ dan S.Kep Ns berjumlah 22 orang dengan persentase 55\%. Tahap perencanaan tidak disusun menurut urutan prioritas $(95,3 \%)$, tujuan tidak mengandung komponen pasien, perubahan perilaku,kondisi pasien $(93,4 \%)$. penelitian ini menunjukkan bahwa pendokumentasian keperawatan berdasarkan kelengkapan perencanaan keperawatan di 
RSUD Kabupaten Mamuju yang masuk dalam kategori kurang lengkap yaitu 46 perawat (49,5\%). Hal ini berbeda dengan hasil penelitian yang dilakukan Hartati, dkk. 2010 dengan judul Analisis Kelengkapan Dokumentasi Proses Keperawatan Pasien Rawat Inap Di RSU PKU Muhammadiyah Gombong Jawa Tengah. Hasil penelitian tersebut menunjukkan bahwa status pasien yang telah dikaji terlihat pendokumentasian tahap perencanaan mendapat skore 59\% (kategori cukup), akan tetapi masih ada beberapa aspek yang belum memenuhi standar asuhan keperawatan.

\section{Pembahasan}

Perencanaan bidang keperawatan dibuat sesuai dengan visi dan misi,filosofi, kebijakan, prosedur, peraturan serta perencanaan strategisorganisasi (Marquis \& Huston, 2013). Perencanaan sebagai upaya memutuskan apa yang akan dilakukan, siapa yang melakukan, bagaimana, kapan dan dimana hal tersebut akan dilakukan. Perencanaan adalah suatu proses memulai dengan sasaran, batasan strategi, kebijakan dan rencana detail untuk mencapainya (Swanburg, 2000).

Asuhan keperawatan merupakan proses atau rangkaian kegiatan pada praktik keperawatan yang diberikan secara langsung kepada klien pasien di berbagai tatanan pelayanan kesehatan. Dilaksanakan berdasarkan kaidah-kaidah keperawatan sebagai suatu profesi yang berdasarkan ilmu dan kiat keperawatan, bersifat humanistik ,dan berdasarkan pada kebutuhan objektif klien untuk mengatasi masalah yang dihadapi klien. Asuhan keperawatan merupakan upaya untuk membantu individu, baik sakit maupun sehat, dari lahir sampai meninggal dunia, dalam bentuk peningkatan pengetahuan dan kemampuan yang dimiliki sehingga individu tersebut dapat secara optimal melakukan kegiatan sehari-hari secara mandiri (Ali, 2002). Proses atau rangkaian kegiatan praktik keperawatan yang langsung diberikan kepada klien/pasien, pada berbagain tatanan pelayanan kesehatan dengan menggunakan metodologi proses keperawatan, berpedoman pada standar keperawatan, dilandasi etik dan etika keperawatan, dalam lingkup wewenang serta tanggung jawab keperawatan didefinisikan sebagai asuhan keperawatan (Kusnanto, 2004). Secara umum asuhan keperawatan diartikan sebagai suatu bentuk pelayanan keperawatan kepada pasien yang bersifat humanistik, caring, professional, dan holistik yang diberikan secara 
langsung pada individu, keluarga dan masyarakat baik sakit maupun sehat yang berpedoman pada standar keperawatan dalam bentuk peningkatan pengetahuan dan kemampuan yang dimiliki sehingga pasien tersebut dapat secara optimal melakukan kegiatan sehari-hari secara mandiri (Ali, 1999; Ali, 2002; Kusnanto, 2004). Asuhan keperawatan ini merupakan bentuk pelayanan profesional yang bertujuan untuk membantu klien dalam pemulihan dan peningkatan kemampuan dirinya melalui tindakan pemenuhan kebutuhan klien secara komprehensif dan berkesinambungan sampai klien mampu untuk melakukan kegiatan rutinitasnya tanpa bantuan dari seorang perawat (Ali, 2002). Bentuk pelayanan ini seyogyanya diberikan oleh perawat yang memiliki kemampuan serta sikap dan kepribadian yang sesuai dengan tuntutan profesi keperawatan, dan untuk itu tenaga keperawatan ini harus dipersiapkan dan ditingkatkan secara teratur, terencana, dan berkesinambungan. Terlaksananya asuhan keperawatan secara optimal memberikan dampak yang positif bagi institusi, salah satunya adalah dengan terciptanya layanan kesehatan yang bermutu dan berkualitas dari sumber daya manusia yang memberikan hasil kerja yang baik terhadap institusinya, baik secara kualitas ataupun secara kuantitas demi tercapainya tujuan organisasi atau institusi.Pelaksanaan asuhan keperawatan ini oleh perawat belum dijadikan sebagai kewajiban utama dalam melaksanakan tugas mereka. Sebagian perawat masih ada yang memberikan asuhan keperawatan kepada klien tidak sebagaimana mestinya sehingga sering terjadi kesalahan dalam mengambil keputusan untuk menyelesaikan masalah klien. Menurut Gillies (1989) perawat yang menggunakan metode keperawatan primer dalam pemberian asuhan keperawatan disebut perawat primer (primary nurse). Pada metode keperawatan primer terdapat kontinutas keperawatan dan bersifat komprehensif serta dapat dipertanggung jawab-kan, setiap perawat primer biasanya mempunyai 4-6 klien dan bertanggung jawab selama 24 jam selama klien dirawat dirumah sakit. Perawat primer ber-tanggung jawab untuk mengadakan komu-nikasi dan koordinasi dalam merencanakan asuhan keperawatan dan juga akan mem-buat rencana pulang klien jika diperlukan. Jika perawat primer sedang tidak bertu-gas, kelanjutan asuhan akan didelegasikan kepada perawat lain (associate nurse).

Perencanaan keperawatan yang dibuat setelah perawat mampu memformulasikan diagnosis keperawatan. Perawat memilih metode khusus dan memilih sekumpulan tindakan alternatif untuk menolong pasien mempertahankan kesejahtraan yang optimal. Semua kegiatan 
keperawatan harus menggunakan sumber-sumber yang tersedia melalui penetapan tujuan jangka panjang dan jangka pendek. Rencana tindakan keperawatan dibuat berdasarkan kebutuhan klien. Pelaksanaan praktik keperawatan dilakukan sesuai dengan rencana yang telah disepakati bersama antara klien dan keluarganya. Pelaksanaan praktik keperawatan harus berpedoman pada standar profesi (Putra, A. 2010). Dalam memberikan pelayanan, perawat memberikan asuhan keperawatan yang terangkum dalam satu siklus yaitu proses keperawatan. Pelaksanaan asuhan keperawatan yang simultan tersebut akan mendatangkan implikasi terhadap tingkat kepuasan klien. Salah satu ciri profesionalisme adalah adanya cara kerja profesional setiap subyek yang ada di dalamnya dan diantaranya didukung dengan dokumentasi yang akurat, jelas, terpercaya dan sah secara hukum (Rimbun LR, 2012). Salah satu sistem yang disusun adalah dengan menyusun struktur pencatatan keperawatan dengan elektronik yang terintegrasi dengan standar keperawatan internasional untuk mendukung kecakapan dan keakuratan perencanaan keperawatan dalam clinical pathway process (Rimbun LR, 2012).

Kepuasan atau ketidakpuasan pelanggan adalah respon pelanggan terhadap evaluasi ketidaksesuaian atau diskonfirasi yang dirasakan antara harapan sebelumnya dan kinerja actual yang dirasakan setelah memakainya (Tse dan Wilson,1998). Kotler (1994) mendasarkan bahwa kepuasan pelanggan adalah tingkat perasaan seseorang setelah membandingkan kinerja yang dirasakan dibandingkan dengan hara-pannya. (dalam Ali Zaidin, 2001). Tingkat kepuasan pasien merupakan fungsi dari perbedaan antara kinerja yang dirasakan dengan harapan. Apabila kinerja dibawah harapan, maka pelanggan akan kecewa. Bila kinerja melebihi harapan , pelanggan akan sangat puas. sedangkan mutu pelayanan kesehatan adalah pelayanan kesehatan yang dapat memuaskan setiap pemakai jasa pelayanan kesehatan yang sesuai dengan tingkat kepuasaan ratarata serata penyelenggaraannya sesuai dengan standart dan kode etik profesi (Azrul Azwar, 1996).

Menurut ANA (American Nurse Association) dalam Suyani, L. (2013) menyebutkan ada enam standar praktik untuk informasi keperawatan yaitu pengkajian, berfokus pada pasien yang meliputi identitas pasien, identifikasi hasil, hasil siklus teknologi informasi dari pasien dan data pasien dalam mendukung adanya perubahan dalam pembuatan keputusan, diagnosa, meliputi seluruh aktivitas yang berhubungan dengan identifikasi hasil yang menggambarkan hasil perawatan yang terukur, perencanaan, penggunaan teknologi yang digunakan untuk menambah 
dan merubah data yang relevan ke dalam perencanaan keperawatan, implementasi, merupakan pemberian tindakan yang nyata kepada pasien, evaluasi, digunakan untuk efisiensi dan efektifitas keputusan, perencanaan dan pelaksanaan untuk meningkatkan praktik keperawatan.

Praktik keperawatan di masa mendatang harus dapat berorientasi pada klien. Hal ini berdasarkan tren perubahan dan persaingan yang semakin ketat saat ini. Perawat Indonesia di masa depan harus dapat memberikan asuhan keperawatan dengan pendekatan proses keperawatan yang berkembang, agar tingkat profesionalitas keperawatan itu semakin Nampak (Nursalam, 2008).

\section{Penutup}

Perlu diadakan pelatihan tentang perencanaan keperawatan dalam asuhan keperawatan secara berkesinambungan sehingga perawat mampu meningkatkan pemahaman asuhan keperawatan dengan baik dan benar, bagi perawat yang mempunyai masa kerja masih baru maupun yang sudah lama. Perlu ada pengawasan dan pemberian reward dan punishment yang jelas serta sikap pimpinan yang tegas dalam hal pelaksanaan dan pencatatan asuhan keperawatan. Setiap perawat harus ditumbuhkan rasa tanggung jawab mengenai ketepatan dalam perencanaan keperawatan dan harus dipertahankan selamanya. Hal ini dilakukan untuk meningkatkan kualitas pelayanan serta meningkatkan praktik keperawatan. Diharapkan Perawat Indonesia di masa depan harus dapat memberikan asuhan keperawatan dengan pendekatan proses keperawatan yang berkembang, agar tingkat profesionalitas keperawatan itu semakin Nampak (Nursalam, 2008). 


\section{Daftar Pustaka}

1 .Achmadi, L,D, L., Linnie Pondaag, Abram Babakal. (2015). Gambaran Tingkat Pengetahuan Perawat Dalam Penerapan Standar Asuhan Keperawatan Di Ruangan Rawat Inap Interna RSUD Datoe Bhinangkang. Journal Keperawatan (e-Kp), 3(3).

2. Agustin, R. 2017. Optimalisasi Pelaksanaan Discharge Planning Melalui Pengembangan Model Discharge Planning Terintegrasi Pelayanan Keperawatan. Jurnal Keperawatan Muhammadiyah 2 (1).

3. Bumulo, M,I., Hendro, B., Bawotong, J. 2017. Pengaruh Manajemen Model Asuhan Keperawatan Profesional Tim Terhadap Kualitas Pelayanan Keperawatab Di Bangsal Pria RSUD Datoe Binangkang Kabupaten Bolaang Mongondow. e-Jurnal Keperawatan (e-Kp), 5 (2)

4. Butar-Butar, J., \& Simamora, R. H. (2016). Hubungan Mutu Pelayanan Keperawatan dengan Tingkat Kepuasan Pasien Rawat Inap di RSUD Pandan Kabupaten Tapanuli Tengah. Jurnal Ners Indonesia, 6(1), 50-63.

5. Christina, P., Agustin, I., Aat, Y. 2019. Analisis Ketidaksinambungan Dokumentasi Perencanaan Asuhan Keperawatan : Metode Ishikawa. Jurnal Ilmiah Kesehatan (JIK), XII (II).

6. Esita, Z. 2015. Semangat Kerja Dan Pelaksanaan Asuhan KeperawatanDi Rumah Sakit Umum Kolaka Sulawesi Tenggara. Jurnal PSIKOLOGIA, 3(1).

7. Hidayah, N. 2014. Manajemen Model Asuhan Keperawatan Profesional (MAKP) Tim Dalam Peningkatan Kepuasan Pasien Di Rumah Sakit. Jurnal Kesehatan, VII (2).

8. Mangole, J,E., Sefty R., A. Yudi Ismanto. (2015). Hubungan Perilaku Perawat Dengan Pendokumentasian Asuhan Keperawatan di Cardiovaskular and BrainCenter RSUP PROF. DR. R. D. Kandou Manado. E-journal Keperawatan (e-Kp), 3(2).

9. S, W, P., Tri, K., Yuyun, P. 2016. Faktor- Faktor Yang Berhubungan Dengan Pendekumentasian Asuhan Keperawatan Di Rumah Sakit Jiwa. NERS JURNAL KEPERAWATAN, 12 (2). 
10. Simamora, R. H. (2005). Hubungan Persepsi Perawat Pelaksana Terhadap Penerapan Fungsi Pengorganisasian Yang Dilakukan Oleh Kepala Ruangan Dengan Kinerjanya Diruang Rawat Inap RSUD Koja Jakarta Utara (Doctoral dissertation, Tesis FIK UI, Tidak dipublikasikan).

11. Supratti, Ashriady. (2016). Pendokumentasian Standar Asuhan Keperawatan Di Rumah Sakit Umum Daerah Mamuju, Indonesia. Jurnal Kesehatan Manarang, 2(1).

12. Zendrato1, M, V., Rr, T,S,H. 2017. Optimalisasi Pengelolaan Asuhan Keperawatan Di InstalasiRawat Jalan Rumah Sakit X. JPPNI, 2 (2). 